INTERNATIONAL JOURNALOF SYSTEMATIC BACTERIOLOGY

Vol. 20, No. 2

April 1970

pp. $227-228$

\title{
PROVISIONAL AGENDA
}

Judicial Commission of the International Committee on Nomenclature of Bacteria

1970, Mexico City

1. Call to order by the Chairman, Dr. P.H. A. Sneath.

2. Membership of the Commission

a. Roll call of members.

b. Presentation and approval of alternates.

c. Loss of Commissioners due to resignation or death.

Note: The present members and officers of the

Judicial Commission are as follows:

loth Class Dr. H. Lautrop (Vice-Chairman)

Dr. P. H. A. Sneath (Chairman)

Dr. J. Sedlak

Prof. Dr. V. M. Zhdanov

11 th Class Dr. T. Gibson

Prof. Dr. S. D. Henriksen

Prof. V. B. D. Skerman

Prof. R. G. E. Murray

12th Class Dr. O.N. Allen

Prof. Dr. O. Kandler

Dr. L. Le Minor

Dr. S. P. Lapage

Permanent Secretaries:

Dr. W.A. Clark

Prof. Dr. H.P.R. Seeliger

Dr. E. F. Lessel (editorial secretary)

3. Minutes of Judicial Commission Meeting held in Leicester in 1968 (see Intl. Jour. Syst. Bacteriol.

Vol. 20, pp. 1-18, January 1970).

4. Appointment of Nominating Committee.

5. Proposals for additional agenda and approval of agenda.

6. Consideration of proposals for emendation of the International Code of Nomenclature of Bacteria, and provisions for publication. 
7. Consideration of requests for Opinions.

8. Report of the Editorial Board.

9. Consideration of Reports and Recommendations to be made to the International Committee.

10. Other business.

11. Election of officers.

12. Adjournment. 